\title{
中学生におけるアレキシサイミア傾向が身体不調感におよぼす影響
}

\author{
瀬戸少年院 \\ 名古屋大学大学院教育発達科学研究科 \\ 反中亜弓
}

$\begin{array}{cc}\text { 福井赤十字病院 } & \text { 放送大学福井学習センター } \\ \text { 寺井 堅祐 } & \text { 梅沢 章男 }\end{array}$

\section{Influence of alexithymic tendencies on somatic complaints of junior high school students}

\author{
Ayumi Tannaka ${ }^{\mathrm{a}, \mathrm{b})}$, Kensuke Terai ${ }^{\mathrm{c})}$ and Akio Umezawa ${ }^{\mathrm{d})}$ \\ (a) Seto Juvenile School, \\ b) Graduate School of Education and Human Development, Nagoya University, \\ c) Fukui Red Cross Hospital, \\ ${ }^{\text {d) }}$ Fukui Study Center, the Open University of Japan)
}

Relationships between somatic complaints and alexithymic tendencies were investigated in junior-high-school students $(N=1,206$; 626 boys and 580 girls) that completed the Somatic Complaint List (SCL) and the Alexithymia Scale for Adolescents (ASA). Results indicated that girls had significantly higher total SCL scores than boys $(d=.18)$, and third-year students had significantly higher total SCL scores than first-year students $(d=.18)$. Moreover, a hierarchical multiple regression analysis revealed that "difficulty identifying feelings" (DIF) subscale of the ASA contributed to higher SCL scores (boys: $\beta=.33, p<.01$; girls: $\beta=.37, p<.01$ ), and furthermore, "difficulty describing feelings" (DDF) subscale played a role in increasing somatic complaints in boys $(\beta=.10$, $p<.05)$. Also, the DIF $\times$ DDF interaction was associated with the total SCL score in girls. These results suggest that alexithymic tendencies, especially DIF and secondarily DDF, influence somatic complaints of junior-highschool students.

Key words: alexithymia, somatic complaints, junior-high-school students

\section{問題と目的}

Sifneos（1973）は，心身症患者に共通する性格特性 として、アレキシサイミアという概念を提唱した。こ れは，不活発な情動機能と空想的な世界の貧困さを意 味する造語である。自らの感情に気付くことや語るこ とが不得手であり，ストレスフルな状況に直面した時 に感情を適切に認知，表現できず，内省や洞察を踏ま えて解決策を探るよりも，行為で解決を図ろうとする 等の特徵がある（Nemiah， Freyberger，\& Sifneos, 1976; Taylor, 1994; Taylor, Bagby, \& Parker, 1991)。

その後,アレキシサイミア測定尺度 Twenty-item Toronto Alexithymia Scale (以下, TAS-20 と略記) が 開発され（Bagby, Parker, \& Taylor, 1994)，同尺度を
使用した研究が数多く行われてきた。その中で, 心身 症状を呈する臨床群と健常群では, 臨床群の TAS-20 得点が有意に高いことが報告されている（たとえば, 小牧他, 2003; Kooiman, Spinhoven, \& Trijsburg, 2002 ; Moriguchi et al., 2007)。また, アレキシサイ ミアは心身症患者に限定的に認められる性格特性では なく，健常群においてもアレキシサイミアが身体愁訴 に関連していることが見出されている。たとえば, Lumley \& Norman（1996）は, 大学生を対象にした 調査で, 一般の学生に掠いてもアレキシサイミア傾向 が認められ，TAS-20 得点と身体愁訴, 抑うつとの間 に有意な正の相関があると報告している。また, 福井・ 野村・小澤・田辺（2010）は，大学生に扔いてアレ キシサイミアの下位尺度である“感情を識別すること の困難さ” (difficulty identifying feeling：DIF，以下， 
“感情識別困難” と略記）という特徴が精神的健康や 身体愁訴に影響することを見出している。このよう に，成人においてはアレキシサイミアの特徴が個人の 健康状態に影響することが立証されてきた。

成人を対象とした研究の進展とは対照的に, 子ども を対象とした研究の蓄積は十分ではない。Honkalampi et al. (2009) は, 13 歳から 18 歳を対象に, TAS-20 と ベック抑うつ質問票, Youth Self Report を調査し, ア レキシサイミア得点の高い子どもは, 不安や抑うつ, 身体愁訴, 思考や注意の困難さ等の得点が高いことを 報告している。わが国においても，Endo et al. (2011) が, 過敏性腸症候群が疑われた中学生は, それ以外の 中学生よりも TAS-20 得点が有意に高いことを報告し ている。しかし，子どもに TAS-20を適用した場合， 一部の下位尺度の信頼性が低いこと，あるいは子ども のアレキシサイミア得点は一般成人よりも高く評価さ れる傾向にあることが報告されている (Moriguchi et al., 2007; Parker, Eastabrook, Keefer, \& Wood, 2010)。 また, Nishimura et al. (2009) は, 言語能力が十分で ない子どもにアレキシサイミア尺度を用いることは難 しいとしており, Parker et al. (2010) も，TAS-20は 項目の言い回しが難しいことから, 子どもが理解しや すいように, 項目の表現を工夫する必要があるとし, 測定したアレキシサイミア傾向が成人と同様の性格特 性として論じることについては慎重であるべきと指摘 している。

子どものアレキシサイミア傾向を探るために, Rieffe, Oosterveld, \& Meerum Terwogt (2006) は, TAS-20 の質問項目を子ども用に書き換えた Alexithymia Questionnaire for Children (以下, AQC と略記) を作 成している。同研究では, AQC と身体不調感を捉え る尺度である Somatic Complaint List（以下, SCL と 略記）を 9 歳から 15 歳の子どもに実施し, AQCの 下位尺度である “感情識別困難” と“感情を他者に語 ることの困難さ” (difficulty describing feeling : DDF, 以下, “感情伝達困難” と略記）は, SCL 得点と正の 相関があることを見出している。この研究は，児童期 と青年期前期の子どもを対象として，アレキシサイミ ア傾向と身体愁訴との関係を分析した数少ない研究の 一つである。しかし，AQCは，3件法を採用してい ることから, 子どもと成人のアレキシサイミア傾向の 比較は難しい。

反中 · 寺井 ·梅沢 (2014) は, AQC (Rieffe et al., 2006）の邦訳と戻し翻訳を経て, TAS-20 と同様の 5 件 法による青年期用アレキシサイミア尺度（Alexithymia Scale for Adolescents：以下, ASA と略記）を作成した。 わが国の中学生を対象に調査を実施し, 確証的因子分 析を実施した結果, ASA は, TAS-20 およびAQCと 同じ因子構造の尺度であることを明らかにした。 Rieffe et al. (2006) と同様に, “外面性志向の思考” (externally-oriented thinking: EOT, 以下, “外的志 向”と略記）を捉える下位尺度の信頼性が十分でな かったものの, 尺度全体の信頼性は.72 と許容される 水準にあることを確認した。さらに, 中学生の ASA 得点は, 女子が男子より有意に高くなるが, 下位尺度 によって性差の現われ方が異なっており, “感情識別 困難” と “感情伝達困難” は女子が高く, “外的志向” は男子が高くなることも報告している。一方, 成人の データでは, “感情識別困難” と “外的志向” の性差 は中学生と同様に確認されているが, “感情伝達困難” の性差は認められていない (Moriguchi et al., 2007)。 このように, ASA で測定される中学生のアレキシサ イミア傾向には, 性格特性として従来指摘されてきた 特徴だけではなく, 発達過程で感情識別や表現の困難 さを自覚する頻度が一過的に高まった影響が反映され ていることも考えられる。したがって, 解釈には慎重 さが求められるものの, ASAにより子どものアレキ シサイミア傾向を検討できる状況が整ったと言える。

先に述べたとおり，TAS-20に準じた尺度で子ども のアレキシサイミア傾向を測定し, 身体不調との関連 を検討した研究は少ない。本邦においては, Endo et al. (2011) が, TAS-20 で測定した子どものアレキシ サイミア傾向と過敏性腸症候群との関連について述べ るに留まっている。しかし, 特定の疾患に限るのでは なく, 子ども達の身体不調感にアレキシサイミア傾向 がどのように関連するのかを検討することも必要であ る。また, Honkalampi et al. (2009) は, TAS-20 得 点と身体不調感の相関を認めてはいるが, 下位尺度を 利用して，アレキシサイミアのどのような特徴が身体 不調感に影響しているかまでは分析していない。 Rieffe et al. (2006) は, アレキシサイミア傾向の中で も “感情識別困難” が身体不調感に最も大きく影響し ていることを見出しているが, 性別による違いを確か めることはしていない。しかし, 前述のとおり中学生 のアレキシサイミア傾向の特徴は, 男女で異なってい ることから，アレキシサイミア傾向と身体不調感の関 係も男女で異なる可能性が考えられる。

そこで, 本研究では, ASA を用いて中学生のアレ キシサイミア傾向と身体不調感との関連, とくに, ア レキシサイミア傾向の各因子が身体不調感におよぼす 影響について, 男女の差異に注目した検討を行う。

\section{方 法}

\section{調査対象および調査手続き}

調査対象は，前報（反中他，2014）と同一であり， 校長と担任教師の承諾が得られた公立中学校 5 校の生 徒 1,470 名である。調査は, 担任教師にあらかじめ実 施手順の説明文を渡し, 各クラスで一斉に調査用冊子 を配布し，その場で実施する方法をとった。なお，倫 
理的配慮として，回答は無記名とし，個人を特定して 分析しないこと, 生徒の自由参加で行うこと, 回答し たくない場合には白紙で提出して良いことを教師から 説明するよう依頼した。その結果, 白紙提出を含め 12 名が参加を辞退した。その後, 記入漏れのない回 答を有効回答とした結果, 最終的に 1,206 名（男子 626 名, 女子 580 名）を分析対象とした（有効回答率 $82.0 \%)$ 。

\section{測定尺度}

身体不調感の測定 SCL（Rieffe et al., 2006; Jellesma, Rieffe, \& Meerum Terwogt, 2007) の日本語 版を作成した。SCLの作成者である Rieffe に邦訳の 承諾を得て翻訳した項目を戻し翻訳し，それを作成者 らに確認した上で使用した。SCL 日本語版は全 11 項 目からなり，過去 2 週間に経験した身体症状の頻度を 「まったくない」(1点) から「よくある」(3 点) の 3 件法により回答を求めた。

アレキシサイミア傾向の測定 反中他（2014）で 作成したASAを使用した。ASA は, Rieffe et al. （2006）のAQCを邦訳した自記式の測定尺度である が, AQCが3 件法であるのに対し，ASA は TAS-20 との比較が可能なように 5 件法を採用している。下位 尺度は, TAS-20 および AQC と同様に, “感情識別困 難”, “感情伝達困難”, “外的志向”の 3 因子であり, ASAの合計得点および各下位尺度得点が高いほど, 感情認知や処理における困難の程度が強いことを示 す。な扮, 本研究の分析対象者は, 反中他 (2014) とは一部異なるため, 再度 ASA の確証的因子分析を 施した。その結果, モデルの適合度は $\mathrm{GFI}=.92$, $\mathrm{AGFI}=.90, \mathrm{RMSEA}=.064$ であり, 基準を満たしてい
ることを再確認した。信頼性係数は, “感情識別困難” で $\alpha=.82$, “感情伝達困難” で $\alpha=.63$, “外的志向” で は $\alpha=.32$ であった。信頼性の低い下位尺度について も, 先行研究と比較することを踏まえ, 項目数を変え ずに以降の分析に用いることにした。

なお，以上の質問紙は，調査の趣旨と目的を述べた フェイスシートに続いて, ASA と SCL, そして本稿 では検討しないが, 怒り表現に関する尺度（反中, 2008）を冊子にして配布した。

\section{結 果}

\section{SCL 日本語版の検討}

Jellesma et al. (2007) と同様に, SCL 日本語版の 11 項目に対して主成分分析を行った（Table 1)。固有 值および寄与率の減衰から，1 次元構造であると考え た。修正済及項目合計相関を算出したところ, 項目 4 , 7 が他の項目に比べて低かった。これは, 項目 4,7 が 反転項目であること, 他の項目と異なり具体的な身体 症状ではなく気分や体調の良さについての設問であっ たことが影響したものと考えられた。SCL 日本語版 11 項目の Cronbach の $\alpha$ 係数は.80であり, 項目 4,7 を除いた $\alpha$ 係数.81 と大差がないため, 原版の SCL と 同様に, 11 項目の合計得点で身体不調感を評価する ことにした。

因子的妥当性を検討するため, 1 因子モデルを作成 し, 潜在因子の分散を 1 に固定して確証的因子分析を 行った。その結果, モデルの適合度は $\mathrm{GFI}=.96$, AGFI=.94, RMSEA=.062 であり, Hu \& Bentler (1999) の GFI $\geqq .90, \mathrm{AGFI} \geqq .90$, Browne \& Cudeck （1993）の RMSEA <.080の基準を満たしていた。

Table 1 The Somatic Complaint List (SCL) according to principal component analysis

\begin{tabular}{lccc}
\hline \multicolumn{1}{c}{ Item } & Factor loading & $\begin{array}{c}\text { Cronbach's } \alpha \\
\text { if item deleted }\end{array}$ & $\begin{array}{c}\text { Corrected item-total } \\
\text { correlations }\end{array}$ \\
\hline 1. 目が回ったり, めまいがすることは & .67 & .78 & .54 \\
2. 疲れたと感じるときが & .56 & .79 & .44 \\
3. お腹が痛いことは & .57 & .79 & .45 \\
4. 体の調子の良いことは & .42 & .80 & .35 \\
5. 腕や足が痛いことは & .67 & .78 & .55 \\
6. 体が弱っていると感じるときは & .66 & .78 & .26 \\
7. 気分が良いときは & .32 & .81 & .53 \\
8. 頭が痛いことは & .65 & .78 & .42 \\
9. 病気ではないかと感じることは & .54 & .79 & .55 \\
10. 体が震えることは & .68 & .78 & .47 \\
11. 吐き気を感じることは & .59 & .79 & \\
\hline Explained variance & 34.28 & & \\
$\alpha$ coefficients & .80 & &
\end{tabular}

Note: Items 4 and 7 are reverse-coded. 
Table 2 Mean scores of the SCL as a function of grade and gender

\begin{tabular}{lcccccccc}
\hline & \multicolumn{2}{c}{ 1st-grade } & & \multicolumn{2}{c}{ 2nd-grade } & & \multicolumn{2}{c}{ 3rd-grade } \\
\cline { 2 - 3 } & Mean & $S D$ & & Mean & $S D$ & & Mean & $S D$ \\
\hline All & 18.35 & 3.75 & & 18.97 & 4.14 & & 19.37 & 4.17 \\
Boys & 17.77 & 3.55 & & 18.51 & 3.93 & & 19.05 & 4.16 \\
Girls & 18.90 & 3.86 & & 19.44 & 4.31 & & 19.78 & 4.15 \\
\hline
\end{tabular}

Table 3 Pearson correlation coefficients between the SCL total score and the ASA total and subscale scores

\begin{tabular}{lcccc}
\hline & & \multicolumn{3}{c}{ SCL } \\
\hline & Mean & $S D$ & $\begin{array}{c}\text { Boys } \\
(r)\end{array}$ & $\begin{array}{c}\text { Girls } \\
(r)\end{array}$ \\
\hline ASA & 53.89 & 9.57 & $.38^{* *}$ & $.33^{* *}$ \\
Difficulty identifying feelings & 16.88 & 5.72 & $.41^{* *}$ & $.40^{* *}$ \\
Difficulty describing feelings & 14.48 & 3.75 & $.33^{* *}$ & $.21^{* *}$ \\
Externally-oriented thinking & 22.54 & 3.81 & .04 & .00 \\
\hline
\end{tabular}

** $p<.01$

\section{中学生の身体不調感の性差・学年差}

Table 2 は, 性および学年別の平均值および標準偏差 を示したものである。性と学年による 2 要因の分散分 析を施した結果, SCL は性の主効果が有意 $\left(F_{(1,1200)}=\right.$ $16.06, p<.01)$ であり，女子の方が身体不調を感じや すいことが分かった $(d=.18)$ 。学年の主効果も有意 であったことから $\left(F_{(2,1200)}=7.24, p<.01\right)$, Tukeyの 多重比較を施したところ, 3 年生と 1 年生の間に有意 差が認められた $(d=.18)$ 。一方, 性と学年の交互作 用は有意ではなかった $\left(F_{(2,1200)}=.24, n s\right)$ 。

\section{身体不調感とアレキシサイミア傾向の関連}

SCL 得点と ASA 得点について男女別にピアソンの 積率相関係数を求めた。その結果, 男女ともに SCL と ASA 得点, “感情識別困難” および “感情伝達困難” との間には有意な正の相関が認められた。Table 3 に は, 相関係数および各尺度の平均值および標準偏差を まとめた。

次に, アレキシサイミア傾向が身体不調感に与える 影響を調べるため, 性と学年を統制変数, ASA 得点を 独立変数, SCL 得点を従属変数として重回帰分析（強 制投入法）を行った。その結果，性 $(\beta=.08, p<.01)$, 学年 $(\beta=.09, p<.01)$, アレキシサイミア傾向 $(\beta=.35$, $p<.01)$ から身体不調感に有意な正の影響が認められ た $\left(R^{2}=.14, p<.01\right)$ 。

さらに, 男女別に階層的重回帰分析を施した。 Step1ではASAの各下位尺度を投入し, Step2では
Table 4 Hierarchical multiple regression for predicting SCL

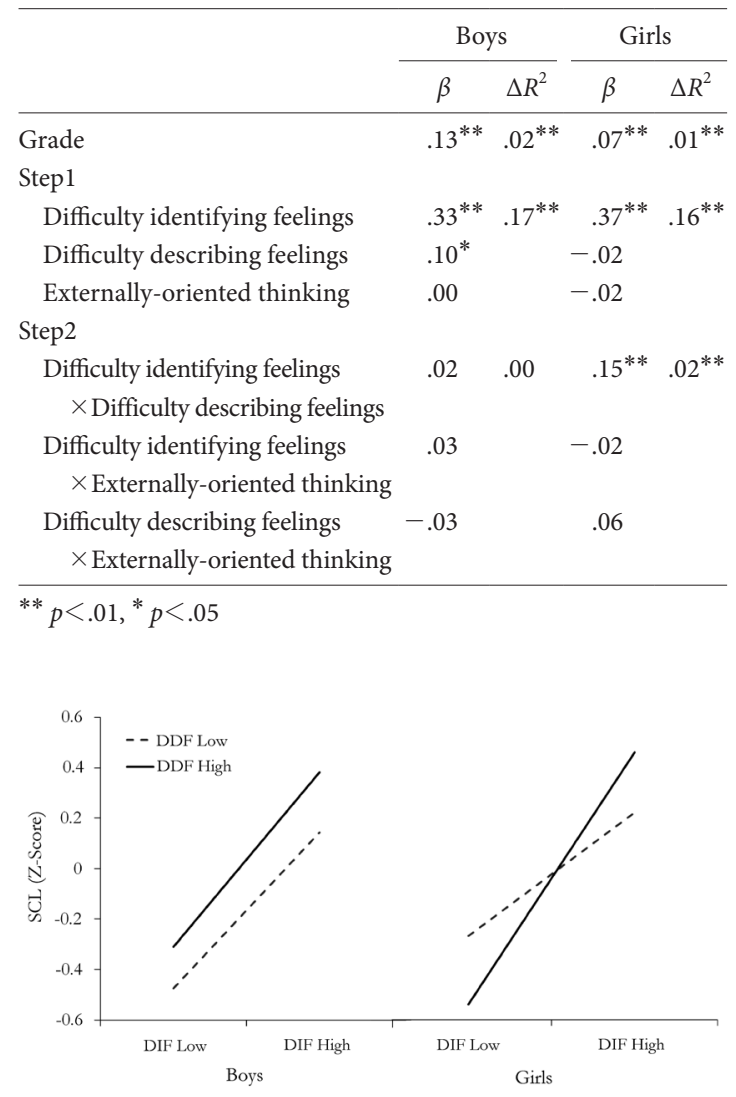

Figure 1. The interaction effect of "difficulty identifying feelings (DIF)" and "difficulty describing feelings (DDF)" on somatic complaints in boys (left) and girls (right)

ASA の下位尺度の交互作用項を投入した。変数は全 て下位尺度ごとに中心化した。その結果, Table 4 に 示すように, Step1では, 男女ともに決定係数 $\left(R^{2}\right)$ は $1 \%$ 水準で有意であり, “感情識別困難”が有意な 正の関連を示し, “外的志向”については有意な関連 は認められなかった。“感情伝達困難”は男子で有意 な正の関連を示したが, 女子には有意な関連が認めら れなかった。Step2では, 女子でのみ“感情識別困難” と “感情伝達困難” の交互作用項に有意な関連が認め られた。そこで, “感情識別困難”と“感情伝達困難” の交互作用項について検討するため, Cohen, Cohen, West, \& Aiken（2003）を参考に, SCL を目的変数と する回帰式に, ASAの各下位尺度の平均得点土1SD をそれぞれ代入し，SCLに対するアレキシサイミア 下位尺度の単回帰直線を求めた。Figure 1 は, 男女別 に得られた単回帰直線を示したものである。男子では 
“感情識別困難”，“感情伝達困難”のそれぞれが高い 者ほど体調不調感が高まるのに対して，女子では“感 情伝達困難” が高い者が, “感情識別困難” も高いと きに体調不調感がより高まることが明らかにされた $(b=.13, t=2.19, p<.05)$ 。

なお, 以上の統計処理についてはAMOS9.0および SPSS19.0を使用した。

\section{考察}

本研究では, SCL 日本語版を作成し, 中学生の身 体不調感とアレキシサイミア傾向との関連を調べた。 まず, SCL 日本語版は, 先行研究（Rieffe et al., 2006; Jellesma et al., 2007) と同様に, 1 次元構造であり, Cronbachの $\alpha$ 係数は.80であったことから, 十分な 信頼性を有していると考えた。分散分析結果から, 中 学生では, 男子よりも女子が, 1 年生よりも 3 年生が 身体不調を多く感じていることが明らかになった。衛 藤（2003）は, 日本人の小学生から高校生を対象と した調査研究で, 男子よりも女子の身体不調感が高い こと, 中学生と高校生においては学年が上がるほど身 体不調感を報告する割合が高くなることを明らかにし ている。また，横山・宮崎・水田・松木・岡崎（2006） は, 中学生に CMI 健康調査票を実施し, 身体症状の 自覚がある者の比率が男子よりも女子で高いことを見 出している。さらに, 高学年になるほど身体症状を自 覚する者が多く，とくに 1 年生と 3 年生の間で統計 的な差が認められると報告している。本研究は, これ らの先行研究を支持する結果であったと言える。しか し, Jellesma et al. (2007) では，本研究と同様に身体 不調感に有意な性差が認められているが, 年齢との相 関は認められていない。これは, 教育制度の違いや進 路選択の時期, 進学に対する構え等の文化差が影響し たものと推察する。

また, SCL と ASAに有意な正の相関が認められ, 中学生の身体不調感とアレキシサイミア傾向との関連 が示唆された。さらに, 重回帰分析の結果から, 中学 生における身体不調感には性別や学年よりもアレキシ サイミア傾向の影響が大きいことが明らかとなった。 福井他（2010）の大学生を対象とした研究では, 階 層的重回帰分析において TAS-20 の下位尺度を独立変 数としたStep の決定係数の増量が $\Delta R^{2}=.035$ となっ ている。使用尺度が異なることから単純に比較するこ とは難しいが, 本研究での決定係数の増量は Table 4 に示したように，男子で $\Delta R^{2}=.17$, 女子で $\Delta R^{2}=.16$ であったことから，青年期の初期にあたる中学生では アレキシサイミア傾向が身体不調感に与える影響は比 較的大きいことが予想される。

とくに“感情識別困難” は, 男子でも，女子でも有 意な関連を示した。同様の結果は, Rieffe et al. (2006)
にも認められている。成人を対象とした先行研究にお いても “感情識別困難” と身体愁訴との関係は安定し て認められている (Deary, Clyde, \& Frier, 1997; Lumley \& Norman, 1996; Mattila et al., 2008)。よっ て, 子どもにも成人にも共通して, 自身の感情が分か らないという特性あるいは状態は身体不調感に最も大 きな影響を与える要因であると考えられる。

一方で, “感情伝達困難” は, 男子では有意な関連 を見せたのに対し，女子では主効果は有意ではなく， “感情識別困難” と “感情伝達困難” の交互作用が有 意であった。すなわち, 男子はいずれの困難さも等し く身体不調感を高めるが, 女子は, 感情表現の難しさ の背景に感情識別の問題があると身体不調感がより高 まると言える。

これまでの研究から, 男子は女子よりも自己防衛的 で（落合・佐藤，1996）, 女子は男子よりも自己開示 の傾向にあることが確かめられている（榎本，2000； 小野寺 ·河村, 2002)。また, 小澤（2010）は, 思春 期における不快情動の拒否感が対処行動に与える影響 について, 女子の場合は問題解決行動の促進に影響す るが, 男子の場合は回避的対処の促進に影響すること を見出している。これらの知見と本研究結果を合わせ て考えてみると, 不快情動が生起したときに, それが 識別できない状態が続くと男女ともに身体不調感が高 まるという点は共通している。これに加えて, 男子の 場合は, 不快情動を識別できたとしても, 自己開示が 伴わず，うまく感情表現できない状態が続くことでも 身体不調感が高まる。一方, 女子は, “感情識別困難” と“感情伝達困難” が男子を上回るが（反中他, 2014), “感情伝達困難” は身体不調感に直接的な影 響を与えていなかった。これは, 女子の積極的に自分 を開示しようとする行動 (榎本, 2000 ; 小野寺 ·河 村, 2002）により，身体不調感への直接的な影響が 緩和された結果と解釈できる。すなわち, 女子の場合 は, 感情の開示に困難を感じていても, 実際には積極 的な自己開示行動ができているため, 身体不調感が高 まるまでには至らないと考えられる。

Rieffe et al. (2006) は, わが国の小学校高学年に相 当する年齢では “感情識別困難” と“感情伝達困難” が身体不調感を強めるが, 中学生段階になると, “感 情識別困難”だけが影響することを報告している。ま た, Deary et al. (1997) の成人の患者を対象とした研 究では, 身体愁訴と“感情伝達困難” との相関は男性 のみに認められている。すなわち, “感情伝達困難” が身体不調感におよぼす影響は, 性別による違いだけ でなく, 発達段階の違いによっても変化する可能性が ある。しかし, 本研究だけでは発達段階による変化に ついて論じることに限界があることから, 今後は調査 対象を高校生以降に広げて検討していく必要がある。

“外的志向”については, 信頼性が十分でない因子 
であるため解釈には慎重さが求められるところである が (Parker et al., 2010; 反中他, 2014), 先行研究と 同様に本研究に扔いても“外的志向” と身体不調感と の間に有意な相関関係は見出されなかった。成人を対 象としたアレキシサイミア傾向と身体不調の自覚, 求

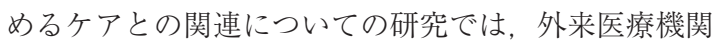
の利用が少なく，心理療法を受けようとしない者はそ うでない者に比べて, 有意に“外的志向”が高いこと が報告されている（Lumley \& Norman, 1996）。つま り, “外的志向” は, 身体不調感に直接影響するわけ ではないが，その後の対処やサポート希求等に影響 し，問題を深刻化させる因子であることが予想され る。したがって, 身体不調感への直接的な影響だけで はなく, 対処行動の面からも検討する必要がある。

近年, 子ども達の不登校や非行等の学校適応の問題 に対して, 教育現場における心理教育や介入の検討が 進められている。これまでの心理教育は認知的もしく は行動的アプローチが中心であったが，自己や他者の 感情を適切に読み取ったり, 自己の感情を統制したり するといった，感情面に着目したアプローチも重要で あることが指摘されている(大対・大竹・松見, 2007)。本研究でも, 自身の感情を識別することの困 難さが最も身体不調感に影響することが明らかになっ ており, 適切な感情表現や伝達のスキルを学ぶだけで はなく，子ども達に自己や他者の感情の認識を促す心 理教育や介入が必要と考える。

利益相反自己申告：申告すべきものなし

\section{引用文献}

Bagby, R. M., Parker, J. D., \& Taylor, G. J. (1994). The twenty-item Toronto Alexithymia Scale-I. Item selection and cross-validation of the factor structure. Journal of Psychosomatic Research, 38, 23-32.

Browne, M. W., \& Cudeck, R. (1993). Alternative ways of assessing model fit. In K. A. Bollen \& J. S. Long (Eds.), Testing structural equation models (pp. 136-162). Beverly Hills, CA: Sage.

Cohen, J., Cohen, P., West, S. G., \& Aiken, L. S. (2003). Applied multiple regression/correlation analysis for the behavioral sciences (3rd ed.). Hillsdale, NJ: Erlbaum Associates.

Deary, I. J., Clyde, Z., \& Frier B. M. (1997). Constructs and models in health psychology: The case of personality and illness reporting in diabetes mellitus. British Journal of Health Psychology, 2, 35-54.

Endo, Y., Shoji, T., Fukudo, S., Machida, T., Machida, T., Noda, S., \& Hongo, M. (2011). The features of adolescent irritable bowel syndrome in Japan. Journal of Gastroenterology and Hepatology, 26, 106-109.

榎本 淳子 (2000). 青年期の友人関係に扮ける欲求 と感情・活動との関連 教育心理学研究, 48, 444-453.

衛藤 隆 (2003). 不定愁訴増加の社会的背景 小児 内科, 35, 1912-1915.

福井 義一·野村 早也佳・小澤 幸世·田辺 肇 (2010). 虐待的養育環境と心身の解離傾向, アレキシサイ ミア傾向, 心身の健康の関連 感情心理学研究, $18,25-32$.

Honkalampi, K., Tolmunen, T., Hintikka, J., Rissanen, M. L., Kylmä, J., \& Laukkanen, E. (2009). The prevalence of alexithymia and its relationship with youth self-report problem scales among Finnish adolescents. Comprehensive Psychiatry, 50, 263-268.

Hu, L.-T., \& Bentler, P. M. (1999). Cut-off criteria for fit indexes in covariance structure analysis. Conventional criteria versus new alternatives. Structural Equation Modeling, 6, 1-55.

Jellesma, F. C., Rieffe, C., \& Meerum Terwogt, M. (2007). The Somatic Complaint List: Validation of a self-report questionnaire assessing somatic complaints in children. Journal of Psychosomatic Research, 63, 399-401.

小牧 元·前田基成·有村 達之. 中田光紀 - 篠 田晴男 ·緒方一子…久保千春 (2003). 日本 語版 The 20-item Toronto Alexithymia Scale （TAS-20）の信頼性, 因子的妥当性の検討 心身 医学, 43, 840-846.

Kooiman, C. G., Spinhoven, P., \& Trijsburg, R. W. (2002). The assessment of alexithymia: A critical review of the literature and a psychometric study of the Toronto Alexithymia Scale-20. Journal of Psychosomatic Research, 53, 1083-1090.

Lumley, M. A., \& Norman, S. (1996). Alexithymia and health care utilization. Psychosomatic Medicine, 58, 197-202.

Mattila, A. K., Kronholm, E., Jula, A., Salminen, J. K., Koivisto, A. M., Mielonen, R. L., \& Joukamaa, M. (2008). Alexithymia and somatization in general population. Psychosomatic Medicine, 70, 716-722.

Moriguchi, Y., Maeda, M., Igarashi, T., Ishikawa, T., Shoji, M., Kubo, C., \& Komaki, G. (2007). Age and gender effect on alexithymia in large, Japanese community and clinical samples: A crossvalidation study of the Toronto Alexithymia Scale (TAS-20). BioPsychoSocial Medicine, 1, 7. 
Nemiah, J. C., Freyberger, H., \& Sifneos, P. E. (1976). Alexithymia: A view of the psychosomatic process. Modern Trends in Psychosomatic Medicine, 3, 430-439.

Nishimura, H., Komaki, G., Igarashi, T., Moriguchi, Y., Kajiwara, S., \& Akasaka, T. (2009). Validity issues in the assessment of alexithymia related to the developmental stages of emotional cognition and language. BioPsychoSocial Medicine, 3, 12.

落合 良行・佐藤 有耕 (1996)。青年期に扔ける友達 とのつきあい方の発達的変化 教育心理学研究, 44, 55-65.

小野寺 正已 ·河村 茂雄 (2002). 中学生用学級内自 己開示尺度の作成と信頼性・妥当性の検討 カウ ンセリング研究, 35, 133-138.

大対 香奈子. 大竹 恵子・松見 淳子 (2007). 学校 適応アセスメントのための三水準モデル構築の試 み 教育心理学研究, 55, 135-151.

小澤 永治 (2010)。思春期に扮ける不快情動への態 度とストレスの関連 心理学研究, 81, 501-509.

Parker, J. D., Eastabrook, J. M., Keefer, K. V., \& Wood, L. M. (2010). Can alexithymia be assessed in adolescents? Psychometric properties of the 20-Item Toronto Alexithymia Scale in younger, middle, and older adolescents. Psychological Assessment, $22,798-808$.
Rieffe, C., Oosterveld, P., \& Meerum Terwogt, M. (2006). An alexithymia questionnaire for children: Factorial and concurrent validation results. Personality and Individual Differences, 40, 123133.

Sifneos, P. E. (1973). The prevalence of alexithymic characteristics in psychosomatic patients. Psychotherapy and Psychosomatics, 22, 255-262.

反中 亜弓 (2008). 中学生に扮ける対人場面別怒り 表現尺度作成の試み 感情心理学研究, 15, 1323.

反中 亜弓 · 寺井 堅祐 - 梅沢 章男 (2014). 中学生 に扔けるアレキシサイミア傾向の学年差, 性差の 検討 感情心理学研究, 22, 11-19.

Taylor, G. J. (1994). The alexithymia construct: Conceptualization, validation, and relationship with basic dimensions of personality. New Trends in Experimental and Clinical Psychiatry, 10, 61-74.

Taylor, G. J., Bagby, R. M., \& Parker, J. D. A. (1991). The alexithymia construct: A potential paradigm for psychosomatic medicine. Psychosomatics, 32, 153-164.

横山 公通 ·宮崎康文 ·水田 嘉美 - 松木 秀明 - 岡 崎 勲 (2006). 中学生の自覚症状と生活習慣に 関する研究 日本公衆衛生雑誌, 53, 471-479.

(2016.1.4 受稿, 2017.2.2 受理) 